\title{
1. The role of private renting in France and the Netherlands compared
}

\author{
Marietta E.A. Haffner
}

\section{BACKGROUND}

After the Second World War the proportion of private rental dwellings in the housing stock of the Western European countries varied from 44 per cent (1955) in France to nearly 60 per cent (1947) in the Netherlands. ${ }^{1}$ In the post-war period, great shifts occurred in the market share of the various tenure categories in many Western European countries. Often the market share of the private rental sector declined as a result of multiple reasons: demolition of existing, poor-quality private rental dwellings; conversion of private rental dwellings into owner-occupied or social rental units; and strict rent regulation and tenant security which characterized the private rental sector in many European countries, sometimes up until the 1980 s. $^{2}$

In the last two decades, this situation has changed somewhat as in several countries, the decline of the private rental sector was stopped by virtue of new (policy) initiatives. ${ }^{3}$ Policy-makers also seem to have rediscovered the potential of the private rental sector. Increasingly, the sector is seen as an alternative for other tenures. This trend seems to have intensified since the start of the Global Financial Crisis (GFC) with the fall of

1 M. Haffner, M. Elsinga and J. Hoekstra, 'Rent Regulation: The Balance between Private Landlords and Tenants in Six European Countries' (2008) 8 European Journal of Housing Policy 223.

2 J. Hoekstra, M. Haffner, H. van der Heijden and M. Oxley, 'Private Rental Landlords in Europe', in S.J. Smith, M. Elsinga, L. Fox O’Mahony, O. Seow Eng, S. Wachter and S. Tsenkova (eds), International Encyclopedia of Housing and Home (Vol. 5, Oxford: Elsevier 2012) 388-9.

3 K. Scanlon, 'Private Renting in other Countries' in K. Scanlon and B. Kochan (eds), Towards a Sustainable Private Rented Sector. The Lessons from other Countries (London: London School of Economics 2011) 19. 
Lehman Brothers in 2007. In France and the Netherlands, politicians increasingly are turning towards the private rental sector. ${ }^{4}$

In this chapter, developments in France and the Netherlands are compared. The Netherlands has continued to follow the earlier trend since the 1980s with a further decline of private renting to about 10 per cent in this century, while France has managed to stabilize the market share of private renting to a little over 20 per cent in the same period. More recently, both countries have been aiming to attract company/organization investment to the private rental sector. This chapter analyzes the factors that have impacted on these different developments, as well as the different ways in which organization (or more narrowly institutional in the sense of insurance company and pension fund) investment is being stimulated via investment subsidies and possibly other measures.

Before sketching the earlier history of private renting compared to the development of the other tenures on the housing market (social renting and owner-occupation) in each country, this chapter first defines private renting based on ownership and the existence of a dwelling allocation system. This exercise clarifies that private landlords may also contribute to providing 'social', 'affordable' or 'subsidized' housing, next to their 'normal' business of providing rental dwellings not based on a public task being involved.

The impact of the GFC on housing policies and more specifically the results for private renting are covered in the more recent history in both countries. A number of key policies impacting on the development of the private rental sector are compared between the countries: tenure neutral subsidy instruments, rent control, and the stimulation of an intermediate price segment on the rental housing market. Based on the most recent developments, the chapter finishes by sketching the expected role of private renting in the housing market of the near future.

\section{WHAT IS PRIVATE RENTING?}

A definition of private renting seems to be relatively easily derived, if private renting coincides with private ownership of housing that is let

4 This chapter started from two TENLAW country reports: M. Haffner, M. van der Veen and H. Bounjouh, TENLAW: Netherlands (2014) 1-167, http://www. tenlaw.uni-bremen.de/reports/NetherlandsReport_09052014.pdf; J. Hoekstra and F. Cornette, TENLAW: France (2014) 1-189, http://www.tenlaw.uni-bremen.de/ reports/FranceReport_09052014.pdf, both accessed 8 August 2017. These publications contain the original sources, which mostly are not repeated here. 
out. Private ownership of rental dwellings by individuals and companies/ organizations would then be considered to comprise the private rental sector. Ownership is usually the foundation of tenure statistics.

In practice, rental dwellings in private ownership are sometimes provided for 'social' purposes; a prominent example here is the bricks-andmortar subsidization of private rental dwellings in the intermediate rental sector (for example, France). These subsidies go hand in hand with conditions or requirements, such as the length of the period of subsidization and special dwelling allocation rules implying that needy households are targeted and that housing with 'social' purposes is serving a public task. Such a social or public task therefore goes hand in hand with an allocation system specifying the queuing rules that determine who will get allocated the next available or vacant social rental dwelling. Considering the other side of the coin, social (public or non-profit) landlords - those fulfilling a public task - also provide non-social rental housing (for example, France and the Netherlands).

Table 1.1 shows that the combination of the concept of ownership with the concept of allocation delivers four ways of defining private renting. Private rental dwellings typically are owned and supplied by private individuals and private companies/organizations (categories 1 through

\section{Table 1.1 Private rental defined according to ownership and allocation of dwellings}

\begin{tabular}{lll}
\hline Categories & Ownership & Allocation \\
\hline 1 & $\begin{array}{l}\text { Private ownership by } \\
\text { individuals and companies } \\
\text { Private ownership by } \\
\text { individuals and companies } \\
\text { Private ownership by } \\
\text { individuals and companies }\end{array}$ & $\begin{array}{l}\text { By market forces } \\
\text { employment or family relationships } \\
\text { Not by market forces: social } \\
\text { allocation criteria linked to receipt of } \\
\text { a tax concession or soft loan linked } \\
\text { to rent levels and household criteria. } \\
\text { Concessions, rent limitations and } \\
\text { allocation conditions may be time } \\
\text { limited }\end{array}$ \\
& & By market forces \\
4 & Non-profit organizations & \\
and public bodies & &
\end{tabular}

Source: $\quad$ M. Oxley, R. Lishman, T. Brown, M. Haffner and J. Hoekstra, Promoting Investment in Private Rented Housing Supply. International Policy Comparison (London: Department for Communities and Local Government, Crown copyright, Queen's Printer and Controller of Her Majesty's Stationery Office 2010) 17. 
3), but could also be owned and supplied by public or non-profit organizations (category 4). A further key distinction is how the dwellings are allocated; either by market forces (categories 1 and 4 ) or via an allocation system (categories 2 and 3). If an allocation system is in place, this could be linked either to employment, for example, private sector employers or other employers, such as churches or the armed forces (category 2). As described, the allocation system could also be linked to the public or social task, for example, providing housing to a needy group determined by policy objectives, for example, low-income households, key workers, or the elderly (category 3 ).

The Table 1.1 classification of private rental dwellings shows that what is understood as private renting may differ across countries. Categories 1 and 3 are of interest in this chapter.

\section{'EARLY' HISTORY}

\section{France - Stabilizing Market Share}

France is an example of a country that stopped the decline of the private rental sector in the 1980s. ${ }^{5}$ The decline started after World War I with the introduction of a strict rent regulation policy. After World War II the share of the private rental sector decreased significantly from being the dominant sector to less than 30 per cent of stock in the 1970s. In the three decades following World War II, which are called the golden age of social housing - 'les trentes glorieuses' - the government not only strongly supported the new construction of social rental dwellings, but also of owneroccupied dwellings, and offered few incentives for the building of private rental homes. The favourable economic development stimulated a growth in incomes, which helped households to be able to access homeownership.

The Housing Act of 1977 simplified the subsidy system. A shift from bricks-and-mortar (also called supply-side) towards personal subsidization was effected, which included the introduction of home improvement subsidies. This trend towards more liberal housing policies, except for the stricter rent control that was implemented in the private rental sector, had as a consequence that organization investors, especially insurance companies, pulled out of the market from the 1970s and 1980s onwards. In the

5 More about the history is collected in P. Boelhouwer and H. Van der Heijden, Housing Systems in Europe: Part I. A Comparative Study of Housing Policy (Delft: Delft University Press 1992) 201-30. 
1990s, housing policy focused also on urban renewal and restructuring. Private rental dwellings were sold off, and if they were of poor quality, they would be demolished.

The private rental sector declined further, until the government introduced a number of measures in the 1980s. One of these is the 1989 Mermaz-Malandain Law which allows the setting of initial rents (at the start of the contract) freely, while rent increases are regulated. From then on contract law has required a minimum contract duration of three years for individual landlords and six years for organization landlords. Prolonging contracts has become routine and the termination of contracts has become easy for tenants, while landlords need reasons, such as a tenant in rent arrears or self-use of dwelling. The 1989 Act is considered to strike a balance in the interests of the tenants and the landlords.

Moreover, a series of tax benefits, aimed at improving investment conditions for private rental landlords, was introduced as of $1984 .^{6}$ These investment subsidies to private renting were motivated by three aims: to provide an alternative to social renting and owner-occupation; to stimulate investments by private persons, after the retreat of the organization investors from the market; and to contribute to the dynamics of local markets by stimulating new production (stock improvement and rent moderation). ${ }^{7}$ In essence, the tax benefits for investment in housing are still in place, although conditions have been altered regularly with changes of government over the past 20 years. ${ }^{8}$ Tax benefits come in an unconditional arrangement to stimulate the supply of private rental dwellings. As a conditional arrangement, the tax benefits aim to stimulate the supply of private rental dwellings for a target group; for example the subsidy being conditional on income and rent level. The policy choice of subsidizing private rental investment fits a complex and complete approach to subsidization without the desire to extend a favourable treatment to one tenure or the other; for example often homeownership. ${ }^{9}$

It seems plausible that the measures have helped to stop the decline of

6 J. Bosvieux and B. Vorms, 'The Private Rented Sector in France', in Scanlon and Kochan (eds), Towards a Sustainable Private Rented Sector. The Lessons from other Countries (London: London School of Economics 2011) 125.

7 J.-P. Schaefer, Aides et financements de projets de logements (Paris: Le Moniteur 2015) 160.

8 In this paragraph this information stems from J. Hoekstra and F. Cornette, TENLAW: France (2014) 44-6, available 8 August 2017 at http://www.tenlaw. uni-bremen.de/reports/FranceReport_09052014.pdf.

9 Bosvieux and Vorms, 'The Private Rented Sector in France' in Scanlon and Kochan (eds), Towards a Sustainable Private Rented Sector. The Lessons from other Countries 135. 
the market share of private renting, even though some form of rent control remained. The development of the private rental sector has stabilized since the second half of the 1980s at a little over 20 per cent, increasing to 23 per cent of the dwelling stock as of 2009, as well as in 2011.

However, private rental dwellings are mainly in the hands of private individual (also called person) landlords. Their share amounted to 22 per cent, while the importance of organization private rental landlords has significantly decreased in recent decades to a share of one per cent. Their share in private rental dwellings dropped from around 12 per cent in 1984 to 4.5 per cent in 2011. In particular, insurance companies have moved their investments to the financial markets because of the higher returns on investment than in rental housing.

\section{Netherlands - Decreasing Market Share}

With 60 per cent of housing stock in 1947, the private rental sector dominated the housing market after World War II. ${ }^{10}$ The policy focus on social renting in combination with relatively strict rent control in order to combat the shortage of housing kicked off the decline of the private rental sector. The growth of the owner-occupied sector, which developed in line with growing welfare from the 1970s onwards and benefited from favourable income tax treatment, chipped in later. By the first decade of this century private renting had declined to less than 10 per cent of stock.

In contrast to France, where organization investors turned their back on private renting, the decline of the Dutch private rental sector was largely the result of the significant fall in the numbers of private individual (also called person) landlords. Non-subsidization and rent control seemed relevant reasons for these landlords. Furthermore, the declining necessity to invest in rental housing in order to supplement retirement income in old age, because of the introduction of a state pension, will also have contributed to the departure of the individual landlords. Also, the sale of private rental dwellings to social landlords often took place as part of large-scale urban renewal programs. The share of private individual landlords declined from 54 per cent in 1974 to less than around 5 per cent of dwelling stock.

On the other hand, the share of the dwellings owned by organizations remained stable. The fact that any (bricks-and-mortar) subsidies for construction that were available were used by organization landlords (including social and private landlords) must be part of the explanation.

10 More about the history is described in Boelhouwer and Van der Heijden, Housing Systems in Europe: Part I. A Comparative Study of Housing Policy 41-77. 
Even though they were affected by rent regulation, like social landlords, private landlords were in fact compensated as they took advantage of these supply-side subsidies that were available, pretty much on the same conditions as social landlords up until the 1970s.

Furthermore, as social landlords did not pay corporate income tax, a tax exemption called Article 10 of the corporate tax code was introduced. ${ }^{11}$ The Article 10 exemption was available for corporate tax paying organizations investing in rental dwellings (mainly investors such as insurance companies; pensions funds already benefited from a standard exemption from corporate income tax) to create a tax exemption for the income from the rental dwellings that were built with bricks-and-mortar subsidies. A financial level playing field was thus created for social landlords and private organization landlords, when they financed investment with bricks and mortar subsidies.

In the 1980s the notion of privatization and making private actors responsible started pervading government policies, as government spending for 'social engineering' in housing continued increasing and was considered to become unaffordable. At the end of the 1980s, a greater role for market forces was set out, as well as an intention to reallocate responsibilities and financial risks away from government. When the subsidies for new construction were reduced sharply after 1989 and phased out by the end of the century, large capital gains as a result of rising house prices in the 1990s partly compensated institutional investors. Their market share remained relatively stable in the period 1947-93 at around 6 per cent of dwelling stock.

In 1995 and 1998 the annual subsidy obligations (bricks-and-mortar subsidies) of the government to the landlords that had been built up in the past - and which were paid as annual revenue or management subsidies for 50 years from the moment a dwelling was constructed - were calculated as one amount. This net present value per rental tenure was paid to the social and private landlords, respectively. This operation resulted in the cutting of the financial ties between the government and all landlords. In the social rental sector this cut made the social, non-profit, accredited (by government) landlords financially independent from government. They were to operate as social entrepreneurs from then on, running the risks of investment themselves, while deploying their societal capital for the public task. In fact, they were to operate as a revolving fund.

11 M.E.A. Haffner, 'The Netherlands', in T. Crook and P.A. Kemp (eds), Private Rental Housing. Comparative Perspectives (Cheltenham, UK and Northampton, MA, USA: Edward Elgar 2014) 52. 
Private institutional landlords would no longer be benefitting from any bricks-and-mortar housing subsidies for new construction either. In addition, the corporate tax exemption (Article 10) for institutional investors investing in subsidized rental dwellings was abolished for new construction in 1992 and for existing stock in 2004. ${ }^{12}$ Their market share in the stock of dwellings finally declined. Decreasing direct returns will have made investors more dependent on returns from capital gains, possibly stimulating (precipitating) investors to sell off their property in function of their desired return on investment. Their business model would normally involve a sale of individual private rental dwellings after 15 or 20 years of operation, before large investments for renovation and modernization involving high costs became necessary. Moreover, the annual construction of private rental dwellings more than halved after $1985 .{ }^{13}$

The cutting of financial ties between the government and the rental sector went almost hand in hand with the creation of a liberalized or deregulated rental segment in both the private and social rental market by 1 July of 1989 for new construction and by 1 July of 1994 for existing dwellings. Whether the rent of a dwelling was (still is) regulated or not depends on the so-called liberalization rent level or threshold rent level, regardless of whether the landlord is a social or a private one. The quality of a dwelling (based on a quality points system) determines in the first instance the maximum rent level that a landlord would be allowed to set for the dwelling in question in the regulated segment of the rental market. Whether the landlord will indeed set this rent level, depends in the second instance on the landlord in question. Social landlords will want to keep rents below the threshold; also because the tenant will be eligible to receive housing allowances (if the income requirement is met). Last, but not least, once the rent is a regulated rent, it can only be raised to a liberalized rent level if a new tenant moves in (given adequate dwelling quality). Illustrative will be the 92 per cent of rental dwellings with regulated rents based on rent level in 2009 versus the 57 per cent of rental stock that could have been provided in the regulated segment of the rental market, if rents were set according to quality. In other words, if rents would have been set as the maximum allowable rent based on the 'adequate' quality norm (as the quality points system prescribes), 43 per cent of rental dwellings could have been offered with a liberalized rent instead of the 8 per cent of rental dwellings (2009).

Even though the cutting of financial ties between government and the rental sector went almost hand in hand with the creation of a deregulated

12 Haffner, 'The Netherlands' 53.

13 Haffner, 'The Netherlands' 53. 
rental segment, the private rental sector continued its decrease in market share to 8 per cent of dwelling stock in 2009.

\section{RECENT POLICIES: ATTRACTING ORGANIZATION INVESTORS AND STIMULATING AN INTERMEDIATE SEGMENT}

The previous section shows that pathways of housing policy affecting private renting have largely been followed in France since the mid to late 1980s, while they were effectuated in the Netherlands in the 1990s. While in France at that time investment subsidies of the type that were already available for social renting and homeownership were introduced for the private rental sector (about one third of the budget going to each tenure, lowest share to private renting), ${ }^{14}$ in the Netherlands they were abolished for new construction in the rental sector. Even though the private rental sector in France has remained of significant size since $(20+$ per cent), and has continued to decrease in the Netherlands (about 8 per cent), both countries lost most of their institutional investment in the private rental sector in due course: insurance companies and pension funds left the private rental market. This fact made both countries strive for an increase in institutional investment in an intermediate or middle segment of the rental market. Different pathways, however, were chosen. The GFC impacted differently in both countries too. The GFC is the starting point of the two following sections on recent housing policies in both countries. It is preceded with a brief characterization of the sector in terms of dwellings, tenants and landlords.

\section{France}

In 2011 , the private rental sector, which is largely supplied by individual or person landlords, caters for young, mobile and small households, mainly because supply comes in mostly smaller (one to three rooms) and older (built before 1949) apartments (almost 70 per cent). That the supply mainly exists in urban areas ( 37 per cent), may be one of the explanations that the median housing expenditure-to-income ratio for tenants in the private rental sector (26.9 per cent) comes close to the one of homeowners repaying a mortgage (27.2 per cent). Both ratios are much higher than the average for all households (18.5 per cent). Scarcity of dwellings in urban

14 Schaefer, Aides et financements de projets de logements 53. 
areas may also play a role in the relatively high housing costs in the private rental sector; especially since the GFC had less impact on the French housing market than in many other countries of Europe.

As in the past, to stimulate the economy, ${ }^{15}$ the GFC caused the government to increase investment subsidies in all tenures; for example, it delivered more generous tax incentives for individual investment in the private rental sector. New construction decreased a little in 2008 and 2009, but started increasing again, in line with the more generous tax schemes. After the end of 2010, the crisis was deemed to have been managed and subsidization levels were lowered. However, affordability problems and a lack of investment by private organizations in private renting remained.

\section{Intermediate rental sector promoted ${ }^{16}$}

Of the about 100,000 extra new dwellings that were financed with the extra crisis funds that the government spent, 30,000 were realized in the social rental sector and 40,000 in the intermediate rental sector (logement locatif intermédiaire). This latter segment of the rental market aims to bridge the gap between social rents and private rents which will be larger in urban than in non-urban areas. Such a rental segment will be accessible to all tenants, given certain income limits, and it will aim to facilitate mobility on the housing market, as well as a housing career in the rental sector.

A government subsidy allows for setting intermediate rents lower than market rents (but higher than social sector rents) and therefore limiting the target group income wise. The first type of subsidy is a low-interest loan available to profit or private and non-profit or social landlords/ investors. Second, individual private rental landlords can make use of tax concessions and refurbishment subsidies. ${ }^{17}$ These tax advantages, which are available conditional on rent levels of dwellings and income requirements of households, are time limited. The limitation in time implies that the intermediate rental dwellings will become private rental dwellings when the subsidy period ends. For the latest tax scheme called Duflot that covered the period 2013-16, the period of subsidization lasted nine years.

15 Bosvieux and Vorms, 'The Private Rented Sector in France' 136.

16 For more information, see J. Hoekstra, Affordable Rental Housing Produced by Private Rental Landlords: the Case of France (Leicester, UK: De Montfort University 2013).

17 See also République Française, Rapport évaluant l'efficacité des dépenses fiscales en faveur du développement et de l'amélioration de l'offre de logements [Report evaluating the efficiency of tax expenditures that aim to stimulate and improve the supply of dwellings] (Paris: République Française 2015) 9-11. 
Increasingly, the schemes have become focused on urban areas (such as the Duflot scheme ${ }^{18}$ ) and on energy efficiency. The Borloo scheme, which has been in place from 2006 onwards and which aims to transform existing dwellings into rental dwellings, is an example of this latter effect. The scheme will run for six years when renovation is excluded, while the term is nine years when renovation is included.

As with the rent levels and the income requirements, rent control and tenant protection in the intermediate rental sector have an intermediate position between social and private renting. For example, in the Duflot scheme, rents should be at least 20 per cent below market rents. While in the private rental sector the standard rent contract will run for three years, the tenancy agreement for an intermediate rental dwelling will be automatically renewed during the subsidy period. When the subsidy period ends, rent control and tenant protection will be regulated by the rules as applicable to private renting.

Between 2003 and 2010 a couple of thousand intermediate rental dwellings were realized per year, ${ }^{19}$ while the expectation was that about 10,000 dwellings a year would be achieved. ${ }^{20}$ As reaction to the GFC, the Scellier scheme was introduced, raising the level of subsidies in the period 2009-12 in comparison with its predecessor scheme, and reaching 3,000 constructed dwellings in 2010, the highest number in the period concerned. In 2015 the government still listed $€ 400$ million tax expenditures for this scheme. The number of beneficiaries is not provided. ${ }^{21}$ It is reported that the improvement subsidies that are available concern 40 per cent of the individual landlords. ${ }^{22}$

Indeed, mostly private individuals are investing in the intermediate rental sector. For many of these investors, the tax advantages will be important for investing in private renting. It has also been made relatively

18 See also République Française, Rapport évaluant l'efficacité des dépenses fiscales en faveur du développement et de l'amélioration de l'offre de logements 9-10.

19 In this paragraph, this information is from J. Hoekstra and F. Cornette, TENLAW: France, 19, available 8 August 2017 at http://www.tenlaw.uni-bremen. de/reports/FranceReport_09052014.pdf.

${ }_{20}$ M. Elsinga, M. Haffner, J. Hoekstra, P. Vandenbroucke, E. Buyst and S. Winters, Beleid voor de private huur. Een vergelijking van zes landen [Policies for the private rental sector. A comparison of six countries] (Brussels: Ministerie van de Vlaamse Gemeenschap 2007) 66.

${ }_{21}$ République Française, Rapport évaluant l'efficacité des dépenses fiscales en faveur du développement et de l'amélioration de l'offre de logements 9.

22 République Française, Rapport évaluant l'efficacité des dépenses fiscales en faveur du développement et de l'amélioration de l'offre de logements 11. 
easy for this target group to become an investor, as the intermediate rental dwellings are offered as a financial product. As a result, geographic targeting has not always been successful. This is stated to be more generally valid for all private renting tax incentives: ${ }^{23}$

Despite some excesses that have sometimes led to housing in places where it is not needed, the incentive schemes to promote rental investment have been effective. But their very success is a problem: the fact that maintaining an adequate supply of rented properties depends so greatly on support from the state makes it difficult to envisage their removal and de facto condemn future governments to perpetuate them.

\section{Organization investment promoted}

Organization landlords did not take up the low-interest loans for intermediate renting that government offered (see previous section), as mostly non-profit landlords made use of them. ${ }^{24}$ However, attracting institutional private capital remains an attractive option for governments. Therefore, the national government has recently introduced tax advantages in order to attract investment by social as well as private organizations to private intermediate renting. ${ }^{25}$ These are concerned with a lower (10 per cent) than normal VAT rate and non-payment of property tax for a period of 20 years.

Last, but not least, a new organization called Fonds Logement Intermédiaire (FLI) (previously 'Argos') aims to attract company investment to the intermediate sector. Official since mid-2014, it was introduced by the Caisse des Dépots (a public investment fund), and within that organization by the group named Société Nationale Immobilière. This group is one of the biggest landlords of social (more than 185,000) and intermediate (almost 90,000) rental dwellings in France.

FLI unites seven other institutional investors (insurance and pension companies) that are familiar with the market of residential investments.

23 Bosvieux and Vorms, 'The Private Rented Sector in France' 136.

24 M. Haffner, J. Hoekstra, C. Tang and M. Oxley, 'Institutional Investment in Social Rental Housing - France, the Netherlands and the United Kingdom explored' (ENHR conference 'Housing and Cities in a time of change: are we focusing on People?' Lisbon, 28 June-1 July 2015) 5.

25 Based on M. Haffner, J. Hoekstra, C. Tang and M. Oxley 'Exploring Institutional Investment in Social Rental Housing in the United Kingdom, the Netherlands and France' (2016) XXX(4) Housing Finance International 31; Based on M. Oxley, C. Tang, C. Lizieri, N. Mansley, M. Makic, M. Haffner and J. Hoekstra, Prospects for Institutional Investment in Social Housing (IPF 2015). 
The aim of this company was to build 10,000 new intermediate rental dwellings in areas with housing shortages in 2014. For 2015 it was expected that another 8,000 intermediate rental dwellings would be realized. These dwellings were to be realized in mixed neighbourhoods in which a quarter of the dwellings should be social. FLI does not construct the new intermediate rental dwellings itself, but acquires them from construction companies and project developers. The fund will run for a period of 20 years.

This initiative seems to be attractive, as it trades off rent control with subsidies on a temporary basis. It also offers an investment product to diversify. However, institutional investors might be put off by a strong societal support for tenure security, a bad reputation when evicting tenants with rent arrears, and changing government policies.

\section{The Netherlands}

The Dutch private rental sector consists of two segments where tenants and dwellings are concerned. The private individual landlords mostly house younger households up to the age of 45 , while those 45 years and over (including those retired) are overrepresented in the stock of organization landlords. Single people are also overrepresented. As in France, those in the private rental sector have higher housing expenditure to income ratios (33.7 per cent) than the households in the social rented sector (23.9 per cent). This may be attributed to the fact that the private rental sector dominates in the urban areas, taking into account that many dwellings in the hands of private individual landlords will be offered with regulated (lower) rents. High ratios are also the result of subsidizing other tenures than private renting, as private renting's declining market share since World War II also seems to indicate. However, the impacts of the GFC on the government budget, as well as a new government policy focus on 'more market', may change the tenure constellation and might offer new chances for private renting; especially with respect to dwellings supplied by organization investors/landlords.

\section{Organization investment promoted}

With hindsight, the government policy change towards more market and less social rental housing started when private investors filed a complaint with the European Commission about social landlords receiving illegal state aid (subsidies). ${ }^{26}$ According to European Union (EU) rules, state aid

26 M. Elsinga, M. Haffner and H. van der Heijden, 'A Unitary Rental Market 
aimed at activities that are used to fulfil a public task is not to be allowed to divert to market activities. This would endanger the level playing field between suppliers for these market activities. And as social landlords were also constructing commercial housing such as dwellings with a liberalized (or deregulated) rent, the threat of subsidies leaking away was deemed realistic by the Commission. Negotiations between the Commission and the Dutch government resulted in the decision of the Commission issued in December 2009. It entailed setting an income limit for the allocation of social rental housing. The income limit agreed on with the EU should affect the demand for private rental housing positively in comparison to the situation without an income limit. ${ }^{27}$

This agreement can be considered to coincide with the ideas of the government, which has been in office for its four-year term since the autumn of 2012. It, as well as its predecessor, are (were) aiming for a more targeted social sector and for creating conditions that allow for better yields for investors, especially in the deregulated rental segment. A more marketconforming rent control is one of the policies that has been implemented with different measures. Furthermore, the possibility to sign temporary tenancy agreements (instead of mostly permanent rental contracts in all of the rental sector) in certain situations was launched. ${ }^{28}$ Last, but not least, rent control has been made stricter for social landlords than for private landlords. ${ }^{29}$

Other than the measures in the rental sector, the access to homeownership was also and still is increasingly being made more difficult. The

in the Netherlands? Theoretical Exploration and Empirical Evidence' (ENHRconference 'Housing in Europe: New Challenges \& Innovations in Tomorrow's Cities', Reykjavik, 29 June-3 July, 2005) and H. Priemus, 'Real Estate Investors and Housing Associations: Level Playing Field? The Dutch Case' (2008) 8 European Journal of Housing Policy 85.

27 Haffner, 'The Netherlands' in Crook and Kemp (eds), Private Rental Housing. Comparative Perspectives 63 and Haffner, Van der Veen and Bounjouh, TENLAW: Netherlands, 10, 18-21.

28 Rijksoverheid. 'Meer ruimte voor tijdelijke huurcontracten' [More opportunity for temporary rental contracts], available 8 August 2017 at https://www. rijksoverheid.nl/onderwerpen/tijdelijk-huren/inhoud/meer-ruimte-voor-tijdelijkehuurcontracten; C.J. Huisman, 'Temporary Tenancies in the Netherlands: From Pragmatic Policy Instrument to Structural Housing Market Reform' (2016) 16 International Journal of Housing Policy 418.

29 Rijksoverheid. 'Huren 2017: maximale stijging huursom voor woningcorporaties 1,3 procent [Rents 2017: maximum increase rent income for social landlords 1.3 percent], available 21 September 2017 at https://www.rijksoverh eid.nl/onderwerpen/huurwoning/nieuws/2016/12/28/huren-2017-maximale-stijg ing-huursom-voor-woningcorporaties-1-3-procent. 
stricter regulation of mortgage loans in the form of a stepwise reduction of loan-to-value ratios allowed and the stepwise reduction of the favourable income tax treatment of mortgagors were both a reaction to the GFC impacting on the homeownership market. In due course, these types of measure assist in allowing a new housing demand and new housing supply to develop in the private rental sector. ${ }^{30}$

In combination with falling house prices between 2008 and 2013 as a result of the GFC impacting negatively on the numbers of dwellings constructed and sold, the balance between house prices and rent levels restored in 2013, making investment in private rental dwellings more attractive. ${ }^{31}$ Relatively secure revenues from renting would lead to a welcome return in times of low alternative returns. Furthermore, demographic developments in combination with lagging housing construction also point towards a potential attractive return on investment in private renting in growing urban areas.

\section{Middle-priced segment of rental sector promoted}

The policy measures and developments described in the previous section generally make investments in private renting relatively more attractive than before their implementation. However, a new tax that was introduced is expected to steer the new supply in private rental dwellings towards the deregulated segment of the rental market. Immediately after the fall of the 2010 government in 2012, a sense of urgency made a coalition of five political parties accept a housing proposal (among other proposals), the landlord levy. ${ }^{32}$ The aim of this tax, which was implemented in July 2013, was to have owner-landlords of more than ten dwellings in the regulated rent segment pay this new tax which is based on the value of the dwelling.

As rent-wise 92 per cent of rental dwellings have a regulated rent, while quality-wise 57 per cent are concerned (see above), the rent of one in three dwellings could be deregulated, once a new tenant moves in. This strategy of moving rental dwellings from the regulated and lower rent segment to the deregulated and higher rent segment could become a strategy for landlords to avoid paying the landlord tax. As meanwhile the threshold rent between the regulated and deregulated rental segments of the rental

\footnotetext{
30 Haffner, Van der Veen and Bounjouh, TENLAW: Netherlands, 10, 50.

31 P.M.A. Eichholtz, T.R. Heijdendael, J. Likkel and D.C.L. van Everdingen, Dutch Residential Investments in European Perspective (IVBN/Finance Ideas 2014) $3,20$.

32 Haffner, 'The Netherlands' 64-65; Oxley et al., Promoting Investment in Private Rented Housing Supply. International Policy Comparison 81-2.
} 
market has been frozen, ${ }^{33}$ the point of deregulation for an individual dwelling will be reached earlier than before. Before, the threshold rent level was increased with inflation annually in line with the annual increase of individual rents, as effected by the Dutch government in the system of rent control.

The introduction of the landlord tax went hand in hand with an annual increase of rents as of 2013, determined by government, which would be set higher for households with a higher household income. These extra amounts of rent revenues aimed to deliver the necessary liquidity for landlords, so they would be able to pay the tax. In effect, this implies that the households with a higher household income will increasingly pay a more market-conforming rent and may in due course move out of the social rental sector. These rent increases will contribute to decreasing the gap between the rent levels of a dwelling with a regulated rent and of a dwelling with a deregulated rent. A decreasing gap may stimulate the tenant to move to a rental dwelling in the middle-priced segment of the rental market. As these dwellings hardly exist in the situation where for 92 per cent of rental dwellings government regulates the rents, new supply may be attracted. Mobility of households is another stated objective of this measure of income-based rent increases.

These measures combine to potentially increase the market share of the middle- (and higher-) priced segment of the private rental market over the longer term. Next to striving to deregulate rents as quickly as possible (pending on a new tenant moving in), other actions that will accelerate this trend are constructing purpose-built new private rental dwellings or the sale of social rental dwellings with a regulated rent and the potential to be deregulated to private landlords. For the latter purpose, rules to facilitate transfers have been drawn up. Whether they work or not, remains to be seen.

\section{SUSTAINABLE PRIVATE RENTING?}

The histories of both countries in a nutshell clarify that the decrease of the market share of private renting was the work of private individual or person landlords leaving the sector in the Netherlands in the first instance as the perceived need for producing income in later age decreased with the

33 Rijksoverheid. 'Wat is de huurliberalisatiegrens?' [What is the threshold rent level], available 8 August 2017 at https://www.rijksoverheid.nl/onderwerpen/ huurverhoging/vraag-en-antwoord/huurliberalisatiegrens. 
introduction of the state pension after World War II, but staying in operation as landlords in France.

While in France, institutional (also called company or organization) landlords/investors retreated and private person landlords have since dominated private renting, in the Netherlands they kept up their share of rental stock, albeit small. This came about largely because bricks-and-mortar (or supply-side) subsidies were available to private as well as social landlords under the same conditions. One could speak of neutrality in investment subsidies across rental tenures. Once they became increasingly unattractive and were abolished in the 1990s, the private rental sector has reached a market share of below 10 per cent in the 21 st century. France, on the other hand, introduced tenure neutral government spending, implying the introduction of bricks-and-mortar subsidies for investors in private renting as of the 1980s. France was therefore able to stabilize the market share of the private rental sector at more than 20 per cent of the housing stock.

These nutshell histories per country largely cover the period up to the GFC which started impacting on the housing markets in both countries after the fall of Lehman Brothers in 2007, more so in the Netherlands than in France. The former country introduced austerity measures in the owner-occupied sector and restricted loan-to-value ratios for mortgage loans, making homeownership less accessible than before; thereby making investment in private renting relatively more attractive. France continued to implement a largely tenure-neutral investment subsidy policy with financial or tax instruments, slightly higher at the time of the crisis and lower thereafter.

In the Netherlands the crisis coincided with a policy emphasis on private renting. The Dutch government introduced 'indirect' legal measures which limit the options for social housing (for example income limits) and which limit rent control increasingly to the cheaper stock with a regulated rent, including private and social rental dwellings, and to households with a lower income. The newly introduced landlord tax for tax payers/owners of 11 or more rental dwellings with a regulated (lower) rent, also stimulates - in principle - a move toward supply with a deregulated/liberalized rent in the more expensive or middle-priced segment of the rental market. The Dutch government hopes to bring back institutional investment into the rental market by creating more market-like conditions for these types of investors by restricting the access to social renting in the ways described, as well as to homeownership, while making the rent control system more market-conforming. That in itself will push for demand in the intermediate segment on the rental market, which hardly exists presently as 92 per cent of rental dwellings have a rent that government regulates at the start of a rental agreement, as well as annually. 
In France the development of the intermediate price segment on the rental housing market had already been considered desirable, because of a large gap in rent levels between social rental dwellings and private rental dwellings in urban areas. Stimulating mobility across tenures according to housing preferences caused the focus on this segment of the rental market and the introduction of time-limited tax subsidies which were popular with individual investors/landlords. More recently, France also introduced tax advantages for organization investors to stimulate the intermediate rental segment in-between social and private renting. Furthermore, a real estate investment fund was initiated by a large public landlord of (investor in) social housing. It unites a number of institutional investors. This initiative seems to be attractive, as it trades off, on a temporary basis, rent control with subsidies. It also offers an investment product for diversification.

While France has shown that it has been able to maintain a private rental sector by subsidizing investments, the Netherlands is now experimenting with making the alternative tenures less attractive from an investment point of view. The aim is to create a middle- and higherpriced segment on the rental market and to draw private organization investment onto the market. The future will show to what extent such an approach will deliver a 'sustainable' position for private renting on the housing market.

\section{REFERENCES}

Boelhouwer, P. and Van der Heijden, H., Housing Systems in Europe: Part I. A Comparative Study of Housing Policy (Delft: Delft University Press 1992).

Bosvieux, J. and Vorms, B., 'The Private Rented Sector in France', in Kath Scanlon and Ben Kochan (eds), Towards a Sustainable Private Rented Sector. The Lessons from other Countries (London: London School of Economics 2011) 125-38.

Eichholtz, P.M.A., Heijdendael, T.R., Likkel, J. and van Everdingen, D.C.L., Dutch Residential Investments in European Perspective (Utrecht: IVBN/Finance Ideas 2014).

Elsinga, M., Haffner, M., Hoekstra, J., Vandenbroucke, P., Buyst, E. and Winters, S., Beleid voor de private huur. Een vergelijking van zes landen [Policies for the private rental sector. A comparison of six countries] (Brussels: Ministerie van de Vlaamse Gemeenschap 2007).

Elsinga, M., Haffner, M. and van der Heijden, H., 'A Unitary Rental Market in the Netherlands? Theoretical Exploration and Empirical Evidence' (ENHRconference 'Housing in Europe: New Challenges \& Innovations in Tomorrow's Cities', Reykjavik, 29 June-July 2005).

Haffner, M.E.A., 'The Netherlands' in T. Crook and P.A. Kemp (eds), Private Rental Housing. Comparative Perspectives (Cheltenham, UK and Northampton, MA, USA: Edward Elgar 2014) 48-70. 
Haffner, M., Elsinga, M. and Hoekstra, J., 'Rent Regulation: The Balance between Private Landlords and Tenants in Six European Countries' (2008) 8 European Journal of Housing Policy 217-33.

Haffner, M., Hoekstra, J., Tang, C. and Oxley, M., 'Institutional Investment in Social Rental Housing - France, the Netherlands and the United Kingdom explored' (ENHR-conference 'Housing and Cities in a time of change: are we focusing on People?', Lisbon, 28 June-1 July 2015).

Haffner, M., Hoekstra, J., Tang, C. and Oxley, M., 'Exploring Institutional Investment in Social Rental Housing in the United Kingdom, the Netherlands and France' (2016) XXX(4) Housing Finance International 28-34.

Haffner, M., van der Veen, M. and Bounjouh, H., National Report for the Netherlands, Delft University of Technology: Deliverable No. 3.2 for FP7 project TENLAW: Tenancy Law and Housing Policy in Multi-level Europe (grant agreement no. 290694), 2014, available 8 August 2016 at http://www. tenlaw.uni-bremen.de/reports.html.

Hoekstra, J., Affordable Rental Housing Produced by Private Rental Landlords: the Case of France (Leicester, UK: De Montfort University 2013).

Hoekstra, J. and Cornette, F., National Report for France, Delft University of Technology: Deliverable No. 3.2 for FP7 project TENLAW: Tenancy Law and Housing Policy in Multi-level Europe (grant agreement no. 290694), 2014, available 8 August 2016 at http://www.tenlaw.uni-bremen.de/reports.html.

Hoekstra, J., Haffner, M., van der Heijden, H. and Oxley, M., 'Private Rental Landlords in Europe', in S.J. Smith, M. Elsinga, L. Fox O'Mahony, O. Seow Eng, S. Wachter and S. Tsenkova (eds), 5 International Encyclopedia of Housing and Home (Oxford: Elsevier 2012) 387-92.

Huisman, C.J., 'Temporary Tenancies in the Netherlands: From Pragmatic Policy Instrument to Structural Housing Market Reform' (2016) 16 International Journal of Housing Policy 409-22.

Oxley, M., Lishman, R., Brown, T., Haffner, M. and Hoekstra, J., Promoting Investment in Private Rented Housing Supply. International Policy Comparison (London: Department for Communities and Local Government, Crown copyright, Queen's Printer and Controller of Her Majesty's Stationery Office 2010), available 8 August 2016 at http://www.communities.gov.uk/publications/ housing/investprivaterentedhousing.

Oxley, M., Tang, C., Lizieri, C., Mansley, N., Makic, D., Haffner, M. and Hoekstra, J., Prospects for Institutional Investment in Social Housing (2015) (London: IPF), available 8 August 2016 at http://www.ipf.org.uk/resourceLib rary/prospects-for-institutional-investment-in-social-housing--january-2015-summary-report.html.

Priemus, H., 'Real Estate Investors and Housing Associations: Level Playing Field? The Dutch Case' (2008) 8 European Journal of Housing Policy 81-96.

République Française, Rapport évaluant 'efficacité des dépenses fiscales en faveur du développement et de l'amélioration de l'offre de logements [Report evaluating the efficiency of tax expenditures that aim to stimulate and improve the supply of dwellings] (Paris: République Française 2015).

Rijksoverheid. Meer ruimte voor tijdelijke huurcontracten [More options for temporary rental contracts], available 8 August 2016 at https://www.rijksoverheid.nl/onderwerpen/tijdelijk-huren/inhoud/meer-ruimte-voor-tijdelijke -huurcontracten.

Rijksoverheid. 'Wat is de huurliberalisatiegrens?' [What is the threshold rent 
level], available 8 August 2016 at https:/www.rijksoverheid.nl/onderwerpen/ huurverhoging/vraag-en-antwoord/huurliberalisatiegrens.

Rijksoverheid. 'Huren 2017: maximale stijging huursom voor woningcorporaties 1,3 procent [Rents 2017: maximum increase rent income for social landlords 1.3 percent], available 21 September 2017 at https://www.rijksoverheid.nl/onderwerpen/huurwoning/nieuws/2016/12/28/huren-2017-maximale -stijging-huursom-voor-woningcorporaties-1-3-procent.

Scanlon, K., 'Private Renting in other Countries', in K. Scanlon and B. Kochan (eds), Towards a Sustainable Private Rented Sector. The Lessons from other Countries (London: London School of Economics 2011) 15-44.

Schaefer, J.-P., Aides et financements de projets de logements (Paris: Le Moniteur 2015). 